Lentera Pustaka: Jurnal Kajian Ilmu Perpustakaan, Informasi dan Kearsipan, 4 (2): 57-66, 2018

Copyright (O2018, ISSN: 2302-4666 print/ 2540-9638 online

Available Online at: http://ejournal.undip.ac.id/index.php/lpustaka

\title{
Kolaborasi dan Produktivitas Penulis pada Prosiding Lokakarya Nasional Dokumentasi dan Informasi PDII LIPI Periode 2013-2017
}

\author{
Rochani Nani Rahayu ${ }^{1 *}$, dan T. Tupan ${ }^{2}$ \\ ${ }^{12}$ Pusat Dokumentasi dan Informasi Ilmiah, Lembaga Ilmu Pengetahuan Indonesia, \\ Jalan Jendral Gatot Subroto No. 10 Jakarta 12710, Indonesia. \\ ${ }^{*}$ Korespondensi: nanipdii@yahoo.com
}

\begin{abstract}
[Title : Collaboration and Productivity of Authors nn The Prosiding of National Workshop Documentation and Information PDII LIPI Period 2013 - 2017] Proceedings of the National Workshop on Documentation and Information for the period of $2013-2017$ are reviewed by bibliometric method to find out ; 1) Number of articles; 2) Patterns of authorship; 3) Degree of collaboration; 4) Author productivity. The results showed that : 1) a total of articles are 66 titles, written by 101 author; 2) Most articles written by single author ( 42 title; 63,64\%), followed by two authors (14 titles; 21,21\%), three authors ( 6 titles; 9,09\%), four authors ( 3 titles; 4.55\%), no five collaborating authors, and 6 authors (1 title; 1.51\%); 3) Collaboration degree value found at 0.39 ; 4) Found 10 of the most prolific writers write 2 title articles with the number of Ambar Yoganingrum, Dwi Ridho Aulianto, Heri Abi Burachman Hakim, Himawanto, Madiareni Sulaiman, Putu Laxman Pendit, Rulina Rachmawati, Sadjuga, Tupan and Wahid Nashihuddin, and the average writer / artkel is 1.53. The conclusion of the research is that the author's collaboration in Proceedings of Documentation and Information Workshop period 2013-2015 is still low, because the article is still dominated by individual author. This is reinforced by a low degree of collaboration, and the productivity of the author is also low because no author has written more than 2 articles.
\end{abstract}

Keywords: Author collaboration; Author productivity; Proceedings of the National Documentation and Information; PDII-LIPI

\begin{abstract}
Abstrak
Prosiding Lokakarya Nasional Dokumentasi dan Informasi periode 2013 - 2017 dikaji dengan metode bibliometrik untuk mengetahui ; 1) Jumlah artikel; 2) Pola kepengarangan; 3) Derajat kolaborasi; 4) Produktivitas penulis. Hasil penelitian menunjukkan bahwa : 1) jumlah artikel sebanyak 66 judul dengan jumlah penulis 101 orang; 2) Pola kepengarangan yang diteliti menunjukkan bahwa artikel terbanyak ditulis oleh penulis tunggal yaitu sebanyak 42 artikel (63,64\%), disusul oleh dua penulis sebanyak 14 artikel $(21,21 \%)$, tiga penulis sebanyak 6 artikel (9,09\%), empat penulis 3 artikel (4,55\%), tidak dijumpai penulis yang berkolaborasi secara berlima, dan 6 penulis 1 artikel (1,51\%); 3) Nilai derajat kolaborasi dijumpai sebesar 0,39 dan 4) Dijumpai 10 orang penulis paling produktif menulis 2 judul artikel dengan jumlah yaitu Ambar Yoganingrum, Dwi Ridho Aulia, Heri Abi Burachman Hakim, Himawanto, Madiareni Sulaiman, Putu Laxman Pendit, Rulina Rachmawati, Sadjuga, Tupan dan Wahid Nashihuddin, dan rata - rata penulis/ artkel adalah 1,53. Kesimpulan penelitian adalah bahwa kolaborasi penulis dalam Prosiding Lokakarya Dokumentasi dan Informasi periode 2013 - 2017 masih rendah, karena artikel masih didominasi oleh penulis tunggal. Hal tersebut diperkuat dengan nilai derajat kolaborasi yang rendah, dan produktivitas penulis juga rendah karena tidak ada penulis yang menulis lebih dari 2 artikel.
\end{abstract}

Kata kunci: Kolaborasi pengarang; Produktivitas pengarang; Prosiding Lokakarya Nasional Dokumentasi dan Informasi; PDII LIPI

\section{Pendahuluan}

Pusat Dokumentasi dan Informasi Ilmiah merupakan unit kerja eselon dua di bawah Lembaga Ilmu Pengetahuan Indonesia dengan salah satu tugasnya adalah melakukan dokumentasi atas karya - karya ilmiah di berbagai bidang ilmu pengetahuan di Indonesia sekaligus melakukan diseminasi atas karya 
tersebut. Berdasarkan tugas tersebut maka Pusat Dokumentasi dan Informasi LIPI (PDII LIPI) wajib mengikuti berbagai kemajuan di bidang dokumentasi dan informasi sehingga selalu up date, tidak ketinggalan ilmu pengetahuan di bidang dokumentasi dan informasi. Salah satu cara agar selalu up date terhadap ilmu dokumentasi dan informasi adalah menyelenggarakan Lokakarya Nasional Dokumentasi dan Informasi setiap tahunnya. Adapun tujuan lain dari penyelenggaraan Lokakarya Nasional Dokumentasi dan Informasi adalah untuk memberikan wadah bagi para pakar maupun praktisi di bidang dokumentasi dan informasi untuk menyampaikan hasil penelitian, pemikiran- pemikiran baru, serta berbagai hal baru lain di bidang dokumentasi dan informasi.

Sebagaimana lazimnya seminar, maka hasil dari lokakarya tersebut didokumentasikan dalam prosiding yang dinamakan Prosiding Lokakarya Nasional Dokumentasi dan Informasi . Sejak diselenggarakan pertama kali pada tahun 2011, prosiding tersebut sudah diterbitkan sebanyak 7 kali, dengan demikian sudah tercatat berbagai kemajuan yang terjadi di bidang dokumentasi dan informasi di Indonesia. Berdasarkan hasil penelitian yang tertulis dalam prosiding tersebut diharapkan PDII LIPI dapat memberikan masukkan kepada pimpinan LIPI tentang hal - hal baru unntuk disampaikan sebagai bahan pembuatan kebijakan di bidang dokumentasi dan informasi. Lebih jauh lagi apabila dirasa perlu, maka masukan juga dapat disampaikan kepada Perpustakaan Nasional selaku pembina berbagai jenis perpustakaan yang ada di Indonesia, termasuk perpustakaan khusus, diantaranya adalah PDII LIPI.

Penelitian terdahulu tentang kolaborasi pernah dilakukan oleh Melin dan Persson dalam Oyeniyi, JO (2012) bahwa kolaborasi merupakan suatu bentuk dari interaksi yang memungkinkan komunikasi secara efektif sebagaimana sharing kompetensi dan berbagai macam sumberdaya. Disebutkan bahwa mengingat kolaborasi merupakan proses interaksi alami antara manusia yang bersifat kompleks, maka seberapa besar mereka berkolaborasi tidak mudah untuk dihitung secara kuantitatif. Perhitungan secara kuantitatif diantara mereka seperti analisis data, maupun kontribusi yang bersifat intangible seperi ide, pemikiran yang dikeluarkan sebagai output berupa sebuah tulisan karya ilmiah sangat sulit untuk dihitung.

Menurut Violanti dalam Oyeniyi, JO (2012), disebutkan bahwa kolaborasi merupakan bagian yang esensial dari sebuah proses penelitian. Ditambahkannya ketika dua orang atau lebih peneliti sedang melakukan penelitian, maka mereka akan berdiskusi tentang kemajuan dari penelitian mereka, saling memberikan masukan terhadap draf tulisan mereka, saling menerima sumberdaya sehingga dapat memunculkan ide untuk menyelesaikan penelitian mereka.

Pada bidang ilmu dan informasi dan perpustakaan (Library and Information Sciences) beberapa penelitian tentang kolaborasi telah dilakukan diantaranya oleh Olsgaard and Olsgaard dalam Park, TM (2006) yang berhasil membuat working model untuk penelitian tentang kepengarangan. Adapun yang diteliti meliputi gender, jabatan serta lokasi geografi dari penulis yang berpartisipasi dalam penulisan artikel dari College \& Research Libraries, Library Journals, Library Quarterly, Library Trends dan RQ dari tahun 1968 sampai dengan 1977. 
Thavamani, Kotti (2015) menemukan dari penelitiannya terhadap berkala Collaborative Librarianship periode 2009 hingga 2014 bahwa dari 223 artikel hasil penelitian ditulis oleh 343 penulis diteliti tentang pertumbuhan penulis setiap tahunnya, pola kepengarangan, dan derajat kolaborasi. Dijumpai jumlah rata - rata penulis per artikel adalah 1, 538. Produktivitas tertinggi adalah 0,650 . Derajat kolaborasi penulis rata - rata adalah 0.354 , yang menunjukkan bahwa kontribusi penulis tunggal lebih tinggi dibandingkan kontribusi multi penulis.

Verma, N dan Singh , K; (2017) melakukan penelitian tentang produktivitas penulis dan derajat kolaborasi dari Journal of Librarianship and Information Science (JOLIS), periode 2010 - 2016. Sebanyak 255 artikel dari (JOLIS), setelah diteliti hasilnya menunjukkan bahwa rata - rata jumlah penulis untuk setiap artikelnya adalah 2,27. Derajat kolaborasi penulis diketahui berkisar pada nilai 0,77 - 0,83, dan ini menunjukkan bahwa multi penulis lebih banyak dibandingkan penulis tunggal.

Tupe, S.K dan Khaparde, V (2016) melakukan analisis terhadap Journal of Library and Information sebanyak 171 artikel, pada periode 2011 - 2015. Dijumpai rata - rata penulis perartikel adalah 1,98 dan rata - rata produktivitas setiap penulis adalah 0,50. Derajat kolaborasi selama 2011 2015 berkisar pada 0,52 - 0,68. Rata - rata derajat kolaborasi adalah 0,59 sehingga dapat dikatakan bahwa penulis tunggal lebih sedikit dibandingkan multi penulis.

Singh, K; Nayak, S; Varma, A.K. (2017), meneliti sebanyak 274 artikel yang dipublikasikan dalam The Canadian Journal of Library and Information Practice and Research periode 2010 - 2016. Dijumpai bahwa sebanyak 187 (71,92\%) merupakan penulis tunggal, diikuti oleh penulis yang berkolaborasi dua orang sebanyak $41(15,77 \%), 23$ penulis $(8,85 \%)$ berkolaborasi tiga orang, 7 penulis $(2,69 \%)$ berkolaborasi empat orang dan 2 penulis ( $0,77 \%)$ berkolaborasi lebih dari lima orang.

Alhamdi, F.A; Khaparde, V. (2015), meneliti pola kolaborasi penulis dari 240 artikel yang dimuat dalam Indian Journal Annals of Library and Information Studies periode 2007 - 2013. Hasil yang didapat adalah dari 240 artikel dijumpai 86 orang $(35,83 \%)$ merupakan penulis tunggal, 105 orang $(43,75 \%)$ menulis berdua, 45 orang $(18,75 \%)$ menulis bertiga dan 4 orang (1,67\%) menulis lebih dari empat orang.

Sebanyak 942 artikel yang dipublikasikan dalam Iranian Library and Information Science Journal antara 2005 - 2009, diteliti oleh Saba Siamaki dkk pada tahun 2014 dengan hasil 506 artikel (53.70\%) ditulis oleh penulis tunggal, dan 436 artikel (46,30\%) ditulis oleh multi penulis.

Munazza Jabeen, dkk (2017), meneliti kolaborasi peneliti dari sebanyak 564 artikel yang dipublikasikan dalam jurnal internasional yang diindeks oleh Social Science Citation Index periode 2012 - 2013. Hasil penelitian menunjukkan bahwa pola kepengarangan artikel yang ditulis oleh penulis tunggal sebanyak 148 judul $(26,24 \%)$ dan artikel yang ditulis secara kolaborasi berjumlah 416 judul $(73,76 \%)$. Artikel yang ditulis secara kolaborasi tersebut terdiri atas 35 artikel ditulis secara kolaborasi antar instansi di Cina, sebanyak 38 artikel dikerjakan secara kolaborasi interregional, 72 artikel dikerjakan secara kolaborasi cross regional dan 271 artikel dikerjakan secara kerjasama cross- national. 
Seperti apa yang diuraikan dalam latar belakang di atas, analisis bibliometrik tentang kolaborasi dan produktivitas dilakukan pada jurnal seperti Journal of Librarianship and Information Science, Journal of Library and Information, The Canadian Journal of Library and Information Practice and Research, dan Iranian Library and Information Science Journal. Oleh karena itu maka penulis melakukan analisis bibliometrika terutama tentang kepengarangan serta kolaborasi terhadap prosiding. Hal ini didasari bahwa prosiding juga merupakan sumber informasi penting di bidangnya untuk dapat diikuti serta dimanfaatkan, namun belum banyak yang melakukan evaluasi secara bibliometrik. Adapun prosiding yang dipilih adalah Prosiding Lokakarya Nasional Dokumentasi dan Informasi dengan harapan dapat memberikan gambaran tentang kondisi kolaborasi penulis di bidang dokumentasi dan informasi secara nasional di Indonesia. Ruang lingkup kajian ini meliputi seluruh makalah yang dimuat dalam Prosiding Lokakarya Nasional Dokumentasi dan Informasi 2013 - 2017. Adapun tujuan penelitian adalah untuk mengetahui : 1) Jumlah makalah yang dimuat dalam Prosiding Lokakarya Nasional ; 2) Pola kepengarangan penulis; 3) Derajat kolaborasi penulis

dan 4) Produktivitas penulis

\section{Metode Penelitian}

Penelitian menggunakan metode bibliometrika yaitu dilakukan dengan mengumpulkan serta mencatat data bibliografi dari para penulis yang berkontribusi di dalam Prosiding Lokakarya Nasional Dokumentasi dan Informasi.

\subsection{Sumber data}

Sumber data yang digunakan adalah Prosiding Lokakarya Nasional Dokumentasi dan Informasi periode 2013 - 2017. Data dikumpulkan dari sumber data dan dicatat pada lembaran worsksheet yang sudah dibuat. Adapun variabel yang dicatat berturut-turut adalah jumlah artikel, jumlah penulis yang dicantumkan dalam artikel.

\subsection{Pengolahan Data}

Data yang diperoleh selanjutnya dihitung menggunakan rumus dibawah ini untuk menemukan persentase distribusi artikel, jumlah publikasi yang ditulis oleh penulis tunggal maupun kolaborasi, dan persentase pola kepengarangan.

Data dihitung menggunakan persamaan: $\mathrm{P}=\mathrm{f} / \mathrm{Nx} 100 \%^{1}$

Dalam persamaan ini, P menyatakan persentase distribusi artikel, jumlah publikasi yang ditulis oleh penulis tunggal maupun kolaborasi, dan persentase pola kepengarangan, $\mathrm{F}$ menyatakan frekuensi artikel, dan $\mathrm{N}$ menyatakan jumlah artikel total. 
$\mathrm{C} \quad=\mathrm{Nm} / \mathrm{Nm}+\mathrm{Ns}^{2}$

Dalam persamaan ini $\mathrm{C}$ menyatakan derajat kolaborasi, $\mathrm{Nm}$ menyatakan jumlah artikel yang ditulis oleh multi penulis, dan Ns menyatakan jumlah artikel yang ditulis oleh penulis tunggal.

Data yang telah diolah selanjutnya disajikan dalam bentuk tabel dan grafik untuk selanjutnya dilakukan penarikan kesimpulan.

\section{Hasil Dan Pembahasan}

\subsection{Distribusi Artikel Berdasarkan Tahun}

Jumlah naskah yang didokumentasikan dalam Prosiding Lokakarya Nasional Dokumentasi dan Informasi yang diselenggarkan oleh PDII LIPI dari tahun 2013 sampai 2017 mengalami peningkatan yang signifikan seperti terlihat pada Tabel 1 dan gambar 1

Tabel 2. Distribusi artikel berdasarkan tahun publikasi $2013-2017$

\begin{tabular}{llll}
\hline No & Tahun publikasi & Jumlah artikel & Persentase (\%) \\
\hline 1 & 2013 & 5 & 7,57 \\
2 & 2014 & 9 & 13,64 \\
3 & 2015 & 15 & 22,73 \\
4 & 2016 & 17 & 25,76 \\
5 & 2017 & 20 & 30,30 \\
\hline Jumlah & & 66 & 100 \\
\hline
\end{tabular}

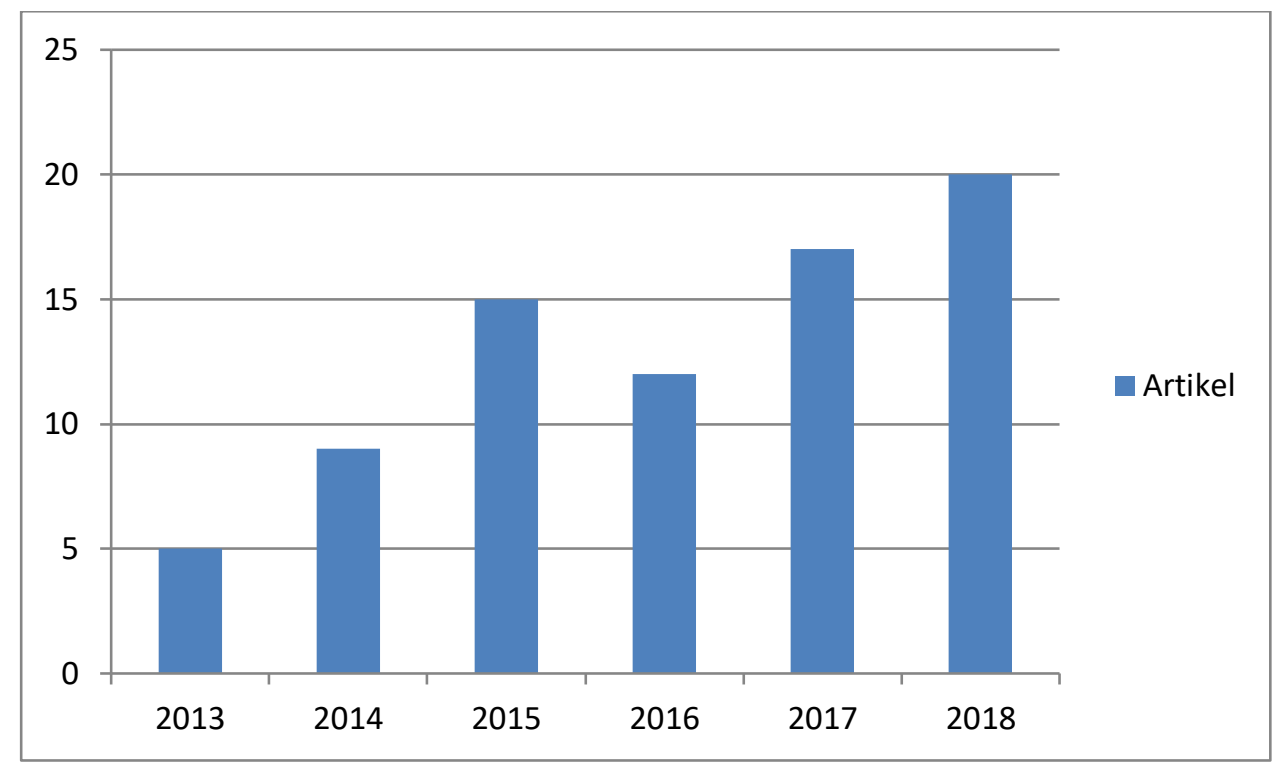

Gambar 1. Jumlah artikel Prosiding Lokakarya Nasional Dokumentasi

Berdasarkan Tabel 1 dan Gambar 1 diketahui bahwa jumlah naskah yang dimuat dalam Prosiding Lokakarya Nasional selama 2013-2017 terbanyak berada pada tahun 2017 yaitu sejumlah 20 naskah (30,30\%), kemudian disusul tahun 2016 sebanyak 17 naskah (25,76\%), tahun 2015 sebanyak 15 naskah (22,73\%). Adapun naskah yang paling sedikit berada pada tahun 2014 yaitu sebanyak 9 naskah $(13,64 \%)$ dan tahun 2013 sebanyak 5 naskah $(7,57 \%)$. 


\subsection{Jumlah Penulis Tunggal dan Penulis Kolaborasi}

Jumlah artikel dalam Prosiding Lokakrya Nasional yang diselenggarakan oleh PDII dari tahun 2013-2017 tercatat sebanyak 66 artikel. Artikel terbanyak ditulis oleh penulis tunggal yaitu sebanyak 42 artikel $(63,63 \%)$ dan sisanya 24 artikel $(36,36 \%)$ dilakukan secara kolaborasi.

Tabel 2. Jumlah publikasi yang ditulis oleh penulis tunggal dan penulis kolaborasi

\begin{tabular}{lllllll}
\hline No & Tahun & $\begin{array}{l}\text { Penulis } \\
\text { tunggal }\end{array}$ & $\begin{array}{l}\text { Penulis } \\
\text { kolaborasi }\end{array}$ & $\begin{array}{l}\text { Tortal } \\
\text { artikel }\end{array}$ & $\begin{array}{l}\text { Persentase } \\
\text { penulis } \\
\text { tunggal }\end{array}$ & $\begin{array}{l}\text { Persentase } \\
\text { penulis } \\
\text { kolaborasi }\end{array}$ \\
\hline 1 & 2013 & 5 & 0 & 5 & 100 & 0,0 \\
2 & 2014 & 6 & 3 & 9 & 66,67 & 33,33 \\
3 & 2015 & 8 & 7 & 15 & 53,33 & 46,67 \\
4 & 2016 & 9 & 8 & 17 & 52,95 & 47,05 \\
5 & 2017 & 14 & 6 & 20 & 70,00 & 30,00 \\
\hline Jumlah & & 42 & 24 & 66 & 63,64 & 36,36 \\
\hline
\end{tabular}

Pada tahun 2013 semua artikel ditulis oleh penulis tunggal, hal ini diduga karena yang dipresentasikan dalam lokakarya tersebut adalah disertasi dari para penulis, jadi hal ini wajar adanya. Jika diamati, maka di setiap tahun persentase penulis tunggal lebih banyak dibandingkan dengan multi penulis, yaitu berturut - turut dimulai dari 2013 hingga 2018 yaitu, $100 \%, 66,70 \%, 53,33 \%, 52,95 \%$, dan $70 \%$.Hal ini disebabkan karena sebagian besar penulis berpatisipasi dalam prosiding tersebut berprofesi sebagai peneliti, dosen

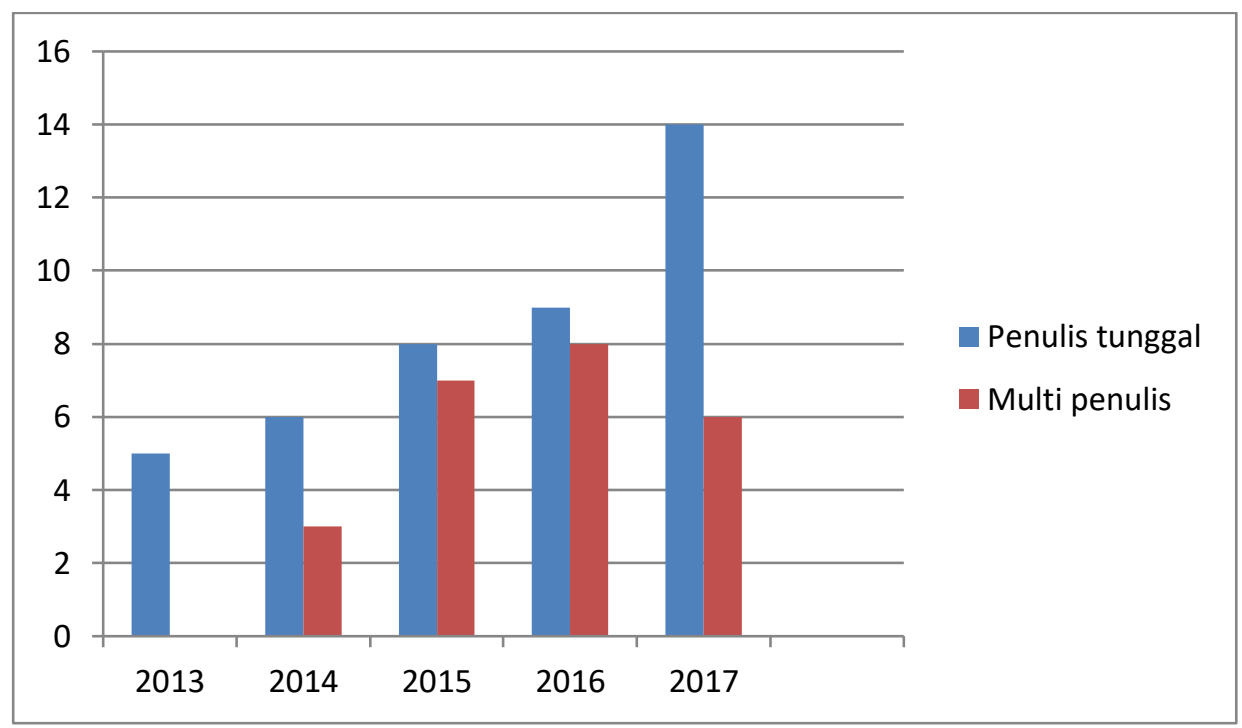

Gambar 2. Jumlah penulis tunggal dan multi penulis 
yang membutuhkan angka kredit untuk kenaikan pangkat maupun jabatan. Sehingga jika penulisan artikel/makalah dilakukan sendiri, nilai angka kreditnya lebih besar dibandingkan jika ditulis secara kolaborasi.

\subsection{Pola Kepengarangan}

Pola kepengarangan dapat dilihat dari Tabel 3 dan Gambar 3 yang menunjukkan bahwa jumlah penulis secara keseluruhan adalah 101 orang dengan jumlah artikel yang ditulis adalah 66 judul. Artikel terbanyak ditulis oleh penulis tunggal yaitu sebanyak 42 artikel $(63,64 \%)$, disusul oleh dua penulis sebanyak 14 artikel (21,21\%), tiga penulis sebanyak 6 artikel (9,09\%), empat penulis 3 artikel (4,55\%), tidak dijumpai penulis yang berkolaborasi secara berlima, dan 6 penulis 1 artikel $(1,51 \%)$.

Tabel 3. Pola Kepengarangan

\begin{tabular}{llllll}
\hline No & Jumlah penlis & Jumlah artikel & Total penulis & $\begin{array}{l}\text { Persentase (\%) } \\
\text { artikel }\end{array}$ & $\begin{array}{l}\text { Persentase } \\
\text { kumulatif } \\
\text { jumlah artikel }\end{array}$ \\
\hline 1 & Single/tunggal & 42 & 42 & 63,64 & 63,64 \\
2 & Dua orang & 14 & 28 & 21,21 & 84,85 \\
3 & Tiga orang & 6 & 18 & 9,09 & 93,94 \\
4 & Empat orang & 3 & 12 & 4,55 & 98,49 \\
5 & Lima penulis & 0 & 0 & 0 & 98,49 \\
6 & Enam penulis & 1 & 1 & 1,51 & 100 \\
\hline Jumlah & & 66 & 101 & 100 & \\
\hline
\end{tabular}

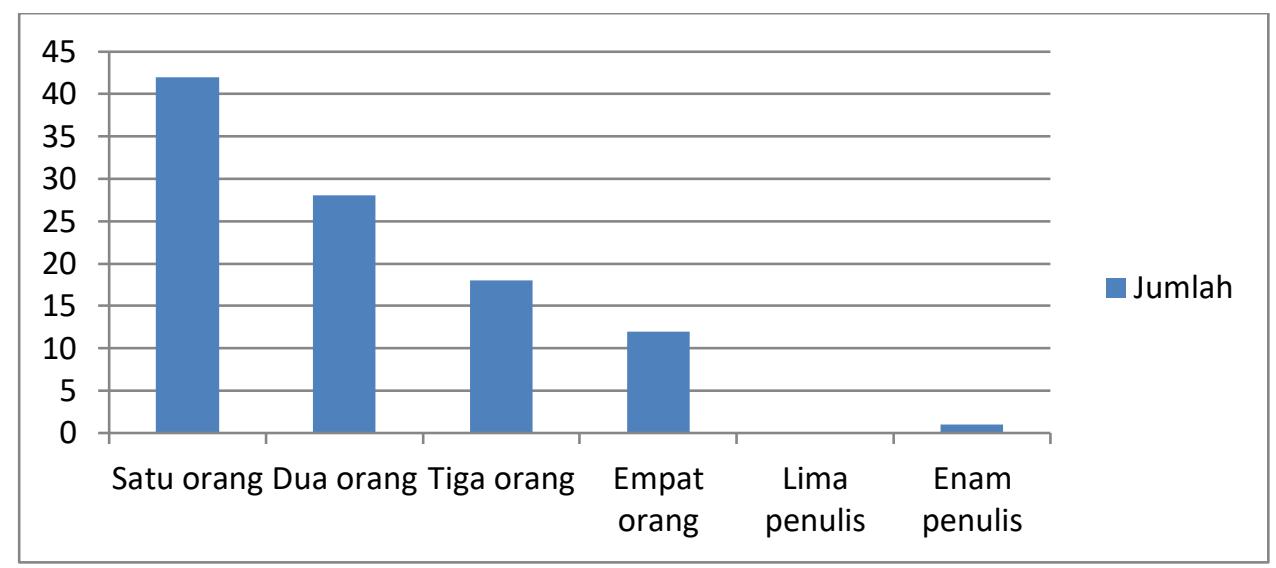

Gambar 3. Jumlah penulis tunggal vs multi penulis

\subsection{Derajat kolaborasi penulis}

Perhitungan derajat kolaborasi dilakukan menggunakan persamaan 2 maka $\mathrm{C}$ menyatakan derajat kolaborasi, Nm menyatakan jumlah artikel yang ditulis oleh multi penulis, sedangkan Ns menyatakan jumlah artikel yang ditulis oleh penulis tunggal. $\mathrm{C}=24 / 24+42=0,39$

Dengan demikian nilai derajat kolaborasi adalah 0,39. Hal ini menunjukkan bahwa penulis tunggal lebih dominan dari pada penulis yang berkolaborasi ( multi penulis). Hal tersebut sesuai jika dibandingkan 
dengan hasil penelitian Singh, K; Nayak, S; Varma, A.K. (2017), meneliti sebanyak 274 artikel yang dipublikasikan dalam The Canadian Journal of Library and Information Practice and Research periode 2010 - 2016. Dari hasil penelitian dijumpai bahwa sebanyak 187 (71,92\%) merupakan penulis tunggal, diikuti oleh penulis yang berkolaborasi dua orang sebanyak $41(15,77 \%), 23$ penulis $(8,85 \%)$ berkolaborasi tiga orang, 7 penulis $(2,69 \%)$ berkolaborasi empat orang dan 2 penulis $(0,77 \%)$ berkolaborasi lebih dari lima orang.

\subsection{Jumlah Rerata Penulis Per artikel}

Tabel 5 menunjukkan bahwa rerata penulis per artikel yang tertinggi ada pada Prosiding Lokakarya Nasional tahun 2017 yaitu 1,60 dan berurut turut disusul pada tahun 2016 dengan nilai rata rata penulis per artikel 1,59, tahun 2014 nilai rata rata per artikel 1,44 dan tahun 2015 nilai rata rata 1,4 dan yang paling kecil tahun 2013 dengan nilai rata rata penulis per artikel hanya 1. Seharusnya rata -rata jumlah penulis per artikel itu terkait dengan networking atau kerjasama penelitian. Semakin artikel itu ditulis banyak orang, maka makin kuat temuan ilmiahnya karena bukan pendapat pribadi, tetapi merupakan hasil kerjasama yang kuat antar penulis/peneliti.

Tabel 5. Jumlah penulis per artikel

\begin{tabular}{llll}
\hline Tahun & Total artikel & Total penulis & Jumlah Penulis/artikel \\
\hline $\mathbf{2 0 1 3}$ & 5 & 5 & 1,00 \\
$\mathbf{2 0 1 4}$ & 9 & 13 & 1,44 \\
$\mathbf{2 0 1 5}$ & 15 & 22 & 1,46 \\
$\mathbf{2 0 1 6}$ & 17 & 28 & 1,64 \\
$\mathbf{2 0 1 7}$ & 20 & 33 & 1,65 \\
\hline Total & 66 & 101 & 1,53 \\
\hline
\end{tabular}

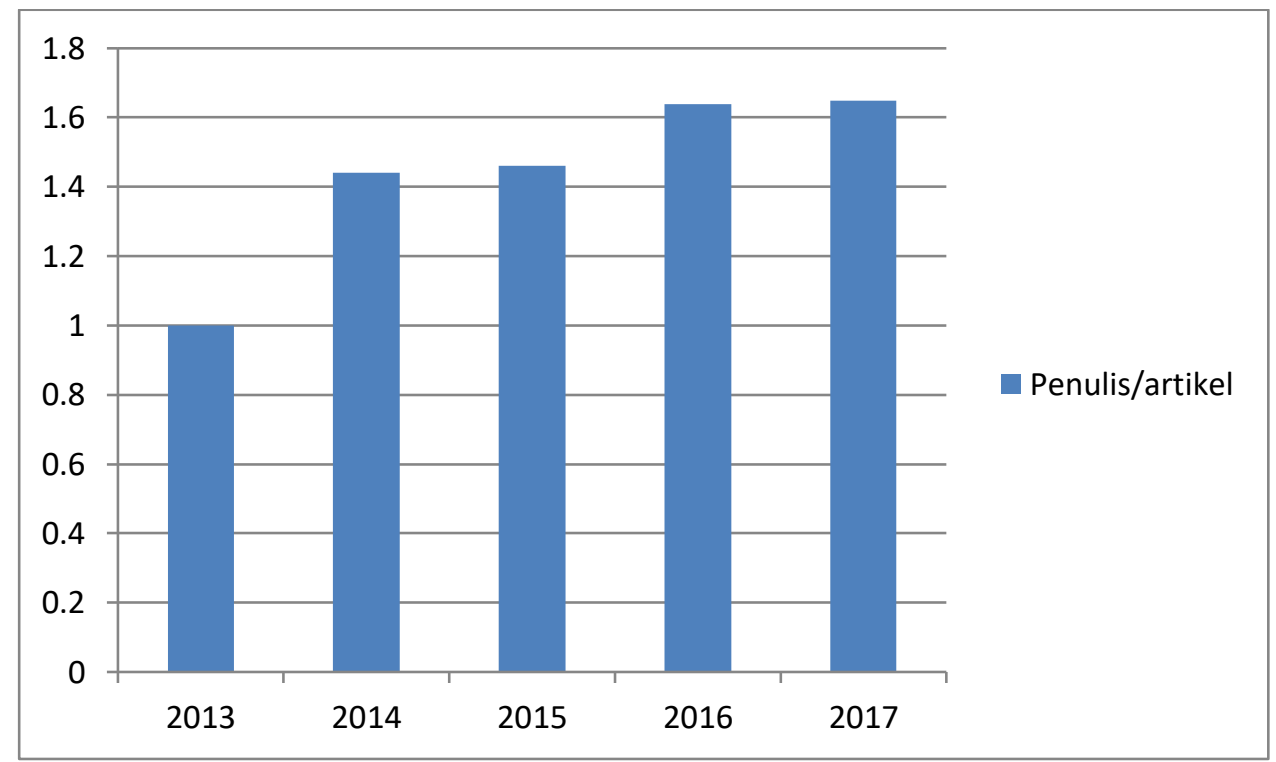

Gambar 4. Jumlah penulis per artikel

\subsection{Produktivitas penulis}


Berdasarkan hasil kajian diketahui bahwa penulis yang makalahnya dipresentasikan dan dimuat dalam Prosiding Lokakarya Nasional Dokumentasi dan Informasi yang diselenggrakan oleh PDII LIPI selama 2013-2017 paling banyak 2 judul artikel. Berdasarkan Tabel 5, dapat diketahui bahwa penulis yang menulis 2 judul artikel ada 10 orang. Adapun ke sepuluh penulis tersebut adalah Ambar Yoganingrum, Dwi Ridho Aulia, Heri Abi Burachman Hakim, Himawanto, Madiareni Sulaiman, Putu Laxman Pendit, Rulina Rachmawati, Sadjuga, Tupan dan Wahid Nashihuddin.

Tabel 5. Penulis yang menulis $>1$ judul

\begin{tabular}{ll}
\hline Nama & Frekuensi \\
Ambar Yoganingrum & 2 \\
Dwi Ridho Aulianto & 2 \\
Heri Abi Burachman Hakim & 2 \\
Himawanto & 2 \\
Madiareni Sulaiman & 2 \\
Putu Laxman Pendit & 2 \\
Rulina Rachmawati & 2 \\
Sadjuga & 2 \\
Tupan & 2 \\
Wahid Nashihuddin & 2 \\
\hline
\end{tabular}

\section{Simpulan}

Berdasarkan hasil penelitian dapat disimpulkan bahwa dari 66 artikel yang ditulis oleh 101 penulis dalam Prosiding Lokakarya Dokumentasi dan Informasi periode 2013 - 2017, kolaborasi antar penulis masih

rendah, karena artikel masih didominasi oleh penulis tunggal. Hal tersebut diperkuat dengan nilai derajat kolaborasi yang rendah, dan produktivitas juga rendah karena tidak ada penulis yang menulis lebih dari 2 artikel selama periode 2013-2017.

\section{Daftar Pustaka}

Alhamdi, F.A; Khaparde, V. 2015. Authorship and Collaborative Patterns in the Annals of Library and Information Studies, 2007 - 2013 : A Scientometric Study; Internasional Journal of Digital Library Services; $5(1): 117-129$.

Jabeen, M. dkk. 2017, Scientific Collaboration of Library \& Information Science Research in China (20122013).Malaysian Journal of Library \& Information Science, 22 (2) : 67 -83. 
Oyeniyi, JO and Taye Paul, O.2012 .Collaborative Strength and Pattern of Authorship among Agricultural

Engineers in Nigeria : A case study of the $2000-2010$ NIAE proceedings. International Journal of Library and Information Science 4 (6) : 115-120.

Park, TM . 2006. Authorship from the Asia Pacific Region in Top Library and Information Science Journals.Asia-PAsific Conference on Library \& Information Education \& Practice, 555 - 564.

Pusat Dokumentasi dan Informasi Ilmiah.dan Ikatan Sarjana Ilmu Perpustakaan dan Informasi Indonesia. 2011 . Prosiding Seminar Ilmiah dan Lokakarya Nasional Dokumentasi. Information for Society: Scientific Point of View. Jakarta, PDII LIPI.

Pusat Dokumentasi dan Informasi Ilmiah. .2013. Prosiding Seminar Ilmiah dan Lokakarya Nasional Dokumentasi dan Informasi : Transfomasi Kepustakawanan Indonesia dalam Era Akses Terbuka. Jakarta, PDII LIPI.

Pusat Dokumentasi dan Informasi Ilmiah. 2014. Prosiding Seminar Ilmiah dan Lokakarya Nasional Dokumentasi dan Informasi : Pusat Dokumentasi Informasi Ilmiah (PDII) LIPI Sebagai Pusat Data dan Informasi Iptek Nasional: Sebuah Grand Design. Jakarta, PDII LIPI.

Pusat Dokumentasi dan Informasi Ilmiah. 2015. Prosiding Seminar Ilmiah dan Lokakarya Nasional Dokumentasi: Pengelolaan Data dan Informasi dalam Perkembangan Teknologi Informasi di Era Big

Data. Jakarta, PDII LIPI.

Pusat Dokumentasi dan Informasi Ilmiah. .2016. Prosiding Seminar Ilmiah dan Lokakarya Nasional Dokumentasi dan Informasi Ilmiah: Pengelolaan Data, Informasi dan Pengetahuan untuk Mendukung

Pembangunan Repositori Nasional. Jakarta, PDII LIPI.

Pusat Dokumentasi dan Informasi Ilmiah. .2017.Prosiding Seminar Ilmiah dan Lokakarya Nasional PDII

Dokumentasi: Pengelolaan Data, Informasi dalam Repositori dan Depositori Nasional. Jakarta,

LIPI.

Siamaki, S,; Gerael, E.; Farahbandi, F. Z. 2014. A Study on Scientific Collaboration and Co authorship Patterns in Library and Information Science Studies in Iran between 2005 and 2009. Journal of Education and Health Promotion, 3: 99.

Singh, K; Nayak, S; Varma, A.K. 2017. A Scientometric Analysis of Partnership : The Canadian Journal of Information Practice and Research (2010 - 2016). International Journal of Library and Information Stuidies 7(3) ; $81-88$.

Subramanyam, K. 1983 Bibliometric Studies of Reseach Collaboration : A Riview . J. Info.Sci. 6 $: 35-37$

Thavamani, Kotti .2015. A study of Authorship Patterns and Collaborative Research in Collaborative Librarianmship, 2009 - 2014. Collaborative Librarianship 7 (2) : 84 - 95 (2015)

Tupe, S.K dan Khaparde, V. 2016. Scientometric Analysis of Pearl : A Journal and Information Science. International Journal of Library and Information Studies, 6 (4) : 1-8. 
Verma, N dan Singh , K; 2017. Author Productivity and Degree of Collaboration in Journal of Librarianship and Information Science (JOLIS) 2010 - 2016. International Journal of Library and Information Studies, 7 (4) : 1-6. 